\title{
Why did the knowledge transition occur in the West and not in the East? ICT and the role of governments in Europe, East Asia and the Muslim world ${ }^{1}$
}

\author{
Ralph Hippe $e^{2}$
}

\begin{abstract}
The invention of a new ICT, the printing press, may have been a fundamental turning point in knowledge transition. But did Gutenberg's printing press succeed in Europe because of, or despite of, government intervention? To answer the question, this paper endeavours to make a comparative analysis of the role of governments in the invention, adoption and dissemination of the printing press in Europe, Korea and the Ottoman Empire. It shows that governments had a major impact on printing technology in both the West and the East.
\end{abstract}

Keywords: knowledge, ICT, government policy, Europe, Korea, Ottoman Empire.

JEL codes: N33, N35, I28, O31.

\section{Introduction}

One of the major debates in recent times has been the Great Divergence, i.e. the divergence of the West and Asia after the Industrial Revolution [e.g. Pomeranz 2000]. The Industrial Revolution itself and the reasons that led to it have sparked important controversies over centuries. Some authors have pointed out the crucial role of human capital and knowledge for long-run economic growth. ${ }^{3}$

\footnotetext{
${ }^{1}$ Article received 30 June 2014, accepted 22 September 2014.

Acknowledgements: I would like to thank Alex Bowen for his inspirational queries that have led to this paper and Roger Fouquet for his valuable comments and suggestions. Financial support by the Global Green Growth Institute is gratefully acknowledged.

${ }^{2}$ Grantham Research Institute on Climate Change and the Environment, London School of Economics and Political Science, Houghton Street, London WC2A 2A, United Kingdom, e-mail: r.hippe@lse.ac.uk.

${ }^{3}$ For a summary of the literature on human capital and economic growth, see Demeulemeester and Diebolt [2011].
} 
For example, Mokyr [2011] proposes that Britain's 'Enlightened Economy' was fundamental to economic growth. However, where did this economy first come from? What triggered the transition from an agriculture-based to an industry-based economy and potentially to a future knowledge-based economy? And why did it not occur elsewhere?

While nothing is certain, one major invention has long been singled out as an important turning point in European history: the printing press. ${ }^{4}$ The invention of the printing press is seen as a major trigger of the enormous increase in knowledge production after the middle of the $15^{\text {th }}$ century. More precisely, it caused the cost of production and the price of books to drop substantively. In other words, the access costs to knowledge were significantly reduced. This was a crucial change because innovation is dependent on the level of access costs [Mokyr 2005]. Larger parts of the European population were now able to acquire and read books. As a consequence, book (and thus knowledge) production took off [see van Zanden 2009; Buringh and van Zanden 2009]. Thus, the printing press represents an innovation that might have caused a slow but continually advancing transition from an economy characterised by a low intensity of knowledge to the potential future knowledge economy. Furthermore, the cumulative long-run effects caused by the new technology may have led to important changes in society. Authors such as Eisenstein [1979] suggest that the printing press was an 'agent of change' that may have ultimately caused the (success of the) Protestant reformation, the Enlightenment and the Industrial Revolution. ${ }^{5}$ Although such ideas have been quite popular there was some lack of more direct evidence on the effects of the printing press for a long time and revisionist ideas have challenged the relevance of the printing press [Johns 1998]. Still, more recent empirical studies point out the significant role of the printing press on subsequent economic growth in Europe [e.g. Baten and van Zanden 2008; Dittmar 2011].

While these studies emphasise the effect of the printing press in Europe, they only partly answer the question as to why the printing press did not spur socio-political change and economic growth elsewhere. This fact is even more surprising as the technology was available in the largest economic hub of the time - Asia. Indeed, the most important inventions upon which the European printing press relied were invented in China, such as paper and movable type printing. In addition metal movable type printing was invented in Korea centuries before Gutenberg's times. Korea is a particularly interesting case because it also had an alphabet (in contrast to China). A pure 'alphabet effect' [Logan 1986] could not apply to this country. But why did metal movable type print-

\footnotetext{
${ }^{4}$ The printing press is only one possible explanation. Alternative explanations include, for example, the development of new trade routes [Broadberry 2013] and the Black Death [Voigtländer and Voth 2012; Broadberry 2013].

${ }^{5}$ For printing and the Protestant reformation, see also Rubin [2013].
} 
ing not lead to a breakthrough and an Industrial Revolution in Korea? While many studies focus on China [e.g. Pomeranz 2000; Landes 2006; Brandt, Ma, and Rawski 2014], Korea appears to have received - somewhat surprisingly only little attention in Western economic literature. This makes the analysis of the Korean case even more valuable. Similarly, why did the Ottoman Empire, another major technological, scientific and political power of the time, not reap the benefits of the printing press? As a crucial intermediary between the West and East Asia, the Muslim world had a long history of adopting major technologies from other regions, as shown by the adoption of paper for the sake of knowledge production.

In consequence this paper investigates the role of the printing press in the cases of Europe, Korea and the Ottoman Empire. In particular it analyses the role of governments and their underlying religious or philosophical legitimacies (i.e. Christianity in Europe, Islam in the Ottoman Empire, Buddhism and Neo-Confucianism in Korea) in this crucial phase of knowledge transition.

The paper shows that this relationship between the rulers and the ruled was significantly affected by the printing press. First of all it emphasises that governments had a major influence on the invention, adoption and dissemination of printing technology in both West and East. Governments (and religious authorities) were often important (producers and) demanders of immaterial and knowledge goods. In addition the printing press, as a major information and communication technology (ICT), had a major impact on the legitimacies of powerful societal stakeholders, particularly of the government and religious authorities. Accordingly they prevented a further dissemination of the printing press. Powerful vested interests, rent seeking and specific values appear as the crucial determinants of the adoption and dissemination of this fundamental new knowledge technology. Moreover the Korean example shows that innovation may be the response to a lack of natural resources for a particular existing technology.

The paper is structured as follows. First, we distinguish between different forms of government legitimacy. Second, we consider the role of governments and religious authorities in the invention, adoption and dissemination of the printing press in Europe. We then take a similar glance at the Ottoman Empire and Korea. Finally, we compare the different experiences. A conclusion sums up the results of the paper.

\section{Forms of government legitimacy}

The printing press may have been an important factor bringing about a crucial shift not only in knowledge production but also in the political authority and legitimacy of central authorities in Europe. This shift may have caused 
the political system to make a transition from feudalism to what we call the modern state [Eisenstein 2002]. Therefore the legitimacy of authorities is an important point of reference for evaluating the socio-political impact of the printing press. We will refer to legitimacy in different parts of the paper. For this reason it is necessary to define what is meant by legitimacy. Legitimacy can be defined as "the feelings, attitudes and trust that the ruled have for the rulers" [Kertcher and Margalit 2005: 3]. This relationship between the rulers of a country and the people is crucial because the rulers may need to ensure sufficient support in order to stay in power. ${ }^{6}$ In this context let us briefly distinguish between different ways of legitimising a government during this long time span. More specifically, Kertcher and Margalit [2005] distinguish amongst three different categories: performance-based, constructed and legal-formal legitimacy.

First, performance-based legitimacy is the most recent and current form in many countries. It was first created with the French Revolution, emphasising that the state rules in a direct way over its citizens. At the same time the state provides security and other rights to citizens. In sum "rulers bargain with their citizens for collective citizens' rights guaranteed by the state in exchange for duties. In return for regularly paying taxes and participation in wars the provisions of security, education, and welfare are assured" [Kertcher and Margalit 2005: 12, referring to Tilly 1992].

Second, constructed legitimacy is derived from morality and has at its core some unifying myths. These unifying myths are repeated and upheld by communication media and the education system. Sometimes they are also emphasised by particular religious practices and specific myths. If these unifying myths are neglected the level of legitimacy falls. The political system may then break down due to the rise of alternative myths that challenge the previous one. One striking example is nationalism which builds upon different myths of the existence of a certain nation. The same can be said for regionalist movements.

Third, legal-formal legitimacy emphasises the role of law and formal processes. They become accepted as being legitimate by a process of socialisation and allow the government to employ force and coercion. This last category backs the other two legitimacies and these other two back each other. In fact all three legitimacies are used by all governments but the emphasis is different according to the specific regime. Some regimes stress constructed legitimacy at the expense of the other two. These regimes are particularly more authoritarian regimes (such as China under Mao). In other cases the performancebased legitimacy is more highlighted (e.g. China after Mao).

\footnotetext{
${ }^{6}$ In addition, legitimacy may also ensure future revenues to rulers [Cosgel, Miceli, and Rubin 2012]. We will comment on this alternative consequence in more detail later on.
} 


\section{Governments and the printing press in Europe}

\subsection{Legitimacy of authorities and the impact of the printing press}

After this brief review of the legitimation devices of governments let us consider in more detail the effects of the printing press on the legitimation of spiritual and secular rulers in Europe. Before the printing press the Middle Ages were characterised by a share of power between the secular powers (i.e. the king, the lords) and the Church. For this reason there was no clearly defined political authority in the modern sense. The organisation of the Church was modelled on the one of the Roman Empire. More specifically, Logan [1986: 164] notes that

$[W]$ ith the fall of Rome there was a total discontinuity in the form of political organization and a natural displacement of the Roman autocracy or ruling class, which no longer held temporal power. In an attempt to preserve their way of life this political elite became members of the hierarchy of the Roman Catholic Church. They borrowed many of the organizational forms of Imperial Rome, which they incorporated into the Church structure. These legacies included the Curia and the office of Pontifex Maximus (the Pope). The canon law [...] [was] based on the principles of Roman law. [...] As had Imperial Rome, the fathers of the Church organized and regulated human affairs through written legal codes.

In contrast, the organisation of 'government' was organised around a deeprooted oral tradition in the Germanic tribes, leading to the feudal order. Government was organised around personal relationships between the governor and his people. Loyalty and trust were key elements in this form of government, and verbal oaths were the symbolic ways of showing allegiance [Logan 1986]. In this feudal order the king did not have the total political authority, whereas (in theory) the Church had it. For example Finer illustrates this fact by stating that "[t]he church was not only a state, it was the state; it was not a society, it was the society" [Finer 1997: 874]. The king was only the temporal ruler, whereas the Church was the spiritual ruler and was in many areas quite independent of the feudal order.

The Church had the power of unchallenged constructed legitimacy, at least for some centuries. ${ }^{7}$ One crucial element of this legitimacy was education. Why was education in general and literacy in particular so important for the Church? In fact Christian beliefs are based on a book (i.e. the Bible). This literary tradition had to be defended and preserved. Literary skills were essen-

\footnotetext{
${ }^{7}$ From the $13^{\text {th }}$ century onwards, its legitimacy may have been decreasing with the formation of secular national kingdoms, new state theories and internal criticisms [Tierney 1988; Feldman 1997; Cosgel, Miceli, and Rubin 2012].
} 
tial for this tradition to be passed on. ${ }^{8}$ Thus the Church had been concerned about (heretical) books to some extent over the centuries before the printing press. Already in $150 \mathrm{AD}$ a ban on heretical books was decreed. However books were not a major concern because few books were produced, the production of books was a slow process and their distribution was limited. In addition, most books could only be accessed in libraries which were generally within religious monasteries. In consequence the Church was the supreme educational authority because it trained the vast majority of educated individuals. Therefore the Church enjoyed an almost exclusive monopoly over book production and thus controlled the diffusion of knowledge and public opinion [Logan 1986]. ${ }^{9}$

The invention of the printing press profoundly changed this world order in Europe. Many more books were produced, the production time was drastically reduced and the price of books decreased tremendously. Thus the demand for books rose to previously unknown high levels. This demand did not only concern spiritual works but also secular ones which were written in European vernacular languages. New political, philosophical and religious ideas spread much more rapidly than before. Importantly, whereas the Church's unifying myths were almost not contested beforehand alternative ideas could now more openly challenge the roots of the belief system and the organisation of the Church. An example might illustrate this. Before the invention of the printing press, John Huss contested the principles of the Church. Thus his writings were burned in 1415 and he was burned himself in 1416 [Putnam 1906; Kertcher and Margalit 2005]. After the invention of the printing press, Luther criticised the Church in a similar way as Huss had done before him. However his use of the printing press made it impossible for the Church to burn all his writings. His pamphlets, translated into the vernacular languages, quickly reached several thousand copies. ${ }^{10} \mathrm{New}$ religious, regional and national identities were gradually developing in addition to the unifying myths of the Catholic Church. In consequence the Church was not able to control public opinion anymore and its unifying myths, which were the foundation of its authority and its constructed legitimacy, eroded. Finally, the centuries-old feudal order began to change. Therefore, the printing press may have been a crucial factor in the transition of political authority, from God to the newly developing nation-state. ${ }^{11}$

\footnotetext{
${ }^{8}$ See the same consequence for Islam and Judaism.

${ }^{9}$ However, the educational leadership may have already been decreasing before the printing press with the creation of universities since the $13^{\text {th }}$ century [Febvre and Martin 1976; Cosgel, Miceli, and Rubin 2012].

${ }^{10}$ Thus Latin also lost its pre-eminence as a vehicle for international communication until the $17^{\text {th }}$ century [Febvre and Martin 1976].

${ }^{11}$ Kertcher and Margalit [2005] note that the printing press was only one factor that led to the loss of control of the Church. Other factors include the Black Plague, the 100 Years' War, and possibly to some extent the introduction of gunpowder into Europe, significantly facilitating war.
} 


\subsection{The reaction of the Church and governments}

Initially the Church did not realise the potential threat of the printing press. Instead it saw the press as a useful means to propagate its faith. Indeed it had been an active promoter of its invention. It had been a major institution creating demand for manuscripts and books for many centuries. Moreover it had long been interested in technology, particularly if it saved labour: its "desire to free clerics from time-consuming earthly tasks led to the introduction and diffusion of power machinery", eventually leading "to an awareness of and attention to time and productivity" [Landes 2006: 9]. Thus its demand importantly influenced Gutenberg's perception of the potential commercial profits that could generate a labour-saving printing press [Guellec 2004]. Once Gutenberg invented the printing press the Catholic Church was also his first customer. ${ }^{12}$ Importantly it only realised too late that it was not able to control its use effectively. ${ }^{13}$ Hence it took more than 70 years for the Church to adjust its existing censorship regulations to the new political and technological situation. Its reaction was to broaden its censorship progressively over time. Thus as Kertcher and Margalit [2005: 18] outline,

[I]n 1479, Pope Sixtus IV authorized the University of Cologne to use ecclesiastical censures against printers, purchasers, and readers of heretical books. The focus was directed at suppressing heretical writing. In 1487, Pope Innocent III published a bull that decreed excommunication, fines, and book burning as punishments for those dealing with heretical books. In 1501, Pope Alexander VI issued an additional bull authorizing universal censorship with the desired goal of homogenizing censorship throughout Christendom. [...] In 1515, [...] Pope Leo $X$ issued a bull forbidding the printing of any book without the church's authorization. The Roman Inquisition was established in 1542 and in 1543 it was ordered that no book, regardless of its contents, should be published or sold without the permission of the Inquisition.

However enforcement was a different matter and it was in many cases rather lax, even in Italy. The French crown was also rather more interested in the potential economic benefits derived from printing than in pursuing the goals of the Church. Similarly England passed an Act of Parliament in 1484 with the aim of attracting foreign printers to the country [Febvre and Martin 1976; Guellec 2004]. In addition there was no unique central religious authority in Protestant countries (e.g. England, parts of Germany, Holland) so that cen-

${ }^{12}$ Further demand came afterwards from universities and finally from individuals [Guellec 2004].

${ }^{13}$ Still almost half of all printed materials were religious works at the end of the $15^{\text {th }}$ century [Martin 1988; Guellec 2004]. It is interesting to note that the demand created by the Catholic Church eventually may have indirectly led to its loss of power. 
sorship took place under the auspices and according to the ideas of secular monarchs. These monarchs aimed more at influencing and controlling public opinion to maintain their own legitimacy [Putnam 1906; Kertcher and Margalit 2005]. For example a royal authorisation was needed in order to become an editor in France. But also kings such as Henry VIII attempted to control the printing industry and the trade of printed materials but again without conclusive success [Guellec 2004]. The most liberal printing regulation probably existed in Holland where only the act of criticising authorities was banned. In addition printers were actively striving to obtain market share in foreign countries. Ironically the setting up of lists of forbidden works might have worked as an unintentional marketing tool for these books. Similar to bestseller lists today being on an index might have increased their publicity and thus their attractiveness, increasing demand and prices [Steinberg 1959; Houston 1988; Kertcher and Margalit 2005].

\section{The Ottoman Empire}

The printing press was not only exported to European countries. Other countries also became acquainted with this innovation, such as the Ottoman Empire. The Ottoman Empire was a major military, economic and scientific power to Gutenberg's times. One could expect that the printing press would have had a similar impact on this advanced economy as it had had in the West. However this was not the case. Therefore we need to explore the reasons in more detail. To this end we begin with a short glance at the characteristics of this empire.

First of all and most evidently, the Ottoman Empire was a Muslim empire. Indeed Islam and the production of books had been inherently intertwined for centuries. To better understand the relationship between Islam and the written word we have to go back to the foundations of Islam. According to Logan [1986] there was a very close connection between the introduction of the written word and alphabetic literacy to Arabia and the rise of the Arab and Muslim culture. Perhaps in some respects similar to the Germanic tribes in Europe, before the foundation of Islam the Arabic peoples consisted of nomadic tribes that were illiterate and did not trust the written word. Their transmission of knowledge and culture was almost exclusively based on oral traditions. The teachings of the Prophet Mohammad made a crucial change to this culture and the central mover in this transformation was the Koran. The effects of the Koran were so fundamental that the oral traditions were to some extent replaced by a new literate, written tradition. ${ }^{14}$ Some authors suggest that this was one of Muhammad's

\footnotetext{
${ }^{14}$ In contrast, Hesse [2002] emphasises that oral transmission was still highly regarded in Islam: "[t]he word «Koran» itself means «recitation», and oral transmission of the living word was always to be preferred over a written transcription. The book was merely an instrument,
} 
intentions: "[e]vidently what was primarily weighing on Muhammad's heart was the observation that the Jews had a book, a revelation, and the Christians had a book and were all progressive and prosperous, whereas the Arabians had no book and were comparatively backward" [Hitti 1964: 31, in Logan 1986: 140]. Logan [1986] believes that this interpretation may be at least partly true.

In any case the spread of Islam was facilitated by writing and vice versa in Arabia and other countries [Logan 1986] ${ }^{15}$ At least in part due to the new literary traditions Islamic culture prospered during the following centuries bringing about major innovations and discoveries. In addition it preserved ancient knowledge from earlier civilisations and later on transmitted this knowledge to the emerging European societies. In fact the developing literary traditions in the Muslim world were importantly boosted by the introduction of a new innovation: paper. This new writing material was originally invented in China and came to the Arab world around the middle of the $8^{\text {th }}$ century. It had a major impact on its literary culture because it was much cheaper than previous media, such as parchment, papyrus and leather [Gibb 1963; Logan 1986]. In consequence the willingness to use this novel writing material probably facilitated the spread of literacy and of the Islamic faith.

Still the reaction to the printing press was quite different. The Ottoman government outlawed the use of printing. Possibly this decision was one of the factors that could have eventually led to the Ottoman's slowly falling behind the emerging West. Why was printing prohibited here? The first explanation focuses on religious beliefs. Printing may have been seen to desacralise the Arabic word and thus the word of Allah in the Koran [Shleifer 1987; Roper 2007]. Similarly, "even though the Islamic religion had accepted paper in order to record the word of Allah, it may have refused to permit the word of Allah to be reproduced by artificial means" [The New Encyclopaedia 1998: 72]. The recreation of these letters was seen to be allowed by qualified individuals only.

Cosgel, Miceli, and Rubin [2012] present an alternative political economy hypothesis focusing on government legitimacy. Note that they define legitimacy in a different way as in the previous sections. More precisely legitimacy is made up here of two sources. The first one is force where military authorities have a comparative advantage. The second one is loyalty which can be particularly used by religious authorities (but also secular authorities such as the nobility).

a lowly tool, to facilitate faithful memorization of the word" [Hesse 2002: 27]. Similar arguments are made by Cosgel, Miceli, and Rubin [2012].

${ }^{15}$ Logan further compares the importance of the introduction of the alphabet to Arabia with what happened in earlier societies: "[w]hat is important about [the] development [from tribal systems of law to Islamic conceptions] is the parallel with the transformation that occurred in Mesopotamia, ancient Israel, and Rome in which the alphabet (or phonetic writing) was accompanied by three developments: 1 . The demise of tribal society, 2 . The rise of law based on the rights and the responsibilities of the individual, 3 . The creation of a universality of mankind that transcends family and tribal links" [Logan 1986: 145]. 
Educators in general and books in particular can serve to create loyalty. In this way religious authorities are supposed to have been a major source of loyalty and thus of legitimacy for governments throughout history. In the view of the authors greater legitimacy brings greater revenues to the rulers. New innovations such as the printing press can significantly influence the sources of legitimacy and increase or decrease revenues.

In consequence, Cosgel, Miceli, and Rubin [2012] argue that Ottoman rulers were still more dependent on the loyalty of religious authorities in the $15^{\text {th }}$ century than their European counterparts on the legitimacy of the Catholic Church. To take Kertcher and Margalit's [2005] terms constructed legitimacy was still more important for the Ottoman rulers. Islamic religious authorities traditionally derived their power through the oral transmission of knowledge. Therefore the printing press might threaten the legitimacy of religious authorities in the Ottoman Empire as it had done in Europe. This would have given an incentive to the rulers not to introduce the technology in order to protect this crucial source of legitimacy and their revenues. The vested interests of particular societal stakeholders and the rent seeking of the rulers would have then prevented the use of this new technology.

In any case the printing of Arabic scripture was forbidden in 1485 in the Ottoman Empire. It may have even been punishable by death [Cosgel, Miceli, and Rubin 2012]. ${ }^{16}$ The centralized structure of the empire assured a strict enforcement of such orders [Macioti 1989; Kertcher and Margalit 2005]. ${ }^{17}$ It took several centuries to open up the Ottoman Empire to printing in Arabic. In fact a first printing press for Arabic was introduced to Istanbul in 1728 but it was closed down again in 1742 due to religious concerns [Kertcher and Margalit 2005]. Printing was at first only allowed on non-religious subjects. This was only relaxed much later. The printing sector was also heavily regulated [Cosgel, Miceli, and Rubin 2012]. Kreiser [2001] claims that the printing press did not have such a great impact on the Ottomans as on the Europeans some centuries earlier. Perhaps this was due to a lack of commercial demand because it would have meant producing a product which was incompatible with religious beliefs. In contrast Cosgel, Miceli, and Rubin [2012] interpret the eventual move to allow printing in Arabic as a consequence of a decrease in the power of religious authorities to confer legitimacy to the Ottoman rulers. Secular authorities had become an increasingly important source of legitimacy during the centuries. These authorities did not derive their power from the transmission of any type of knowledge so that the printing press did not represent a direct threat to

\footnotetext{
${ }^{16}$ Yet there is some controversy on this point. However most of the literature considers it a fact [Cosgel, Miceli, and Rubin 2012].

17 This is not to say that printing was not allowed in other (than Arabic) scripts. For example scripts were printed in Roman, Greek or Armenian scripts in the Ottoman Empire [Cosgel, Miceli, and Rubin 2012].
} 
them. In Kertcher and Margalit's [2005] terms their power was more based on performance legitimacy than on constructed legitimacy. The revenues could also be expected to be positive from the permission to print in Arabic. In consequence the Ottoman rulers were not that dependent on religious authorities as a source of legitimacy anymore and may have decided to increase their revenues. Still it took until 1875 for the first Koran to be printed in the Ottoman capital of Istanbul [Macioti 1989; Kertcher and Margalit 2005].

If we see this development from a perspective on the facilitation of the spread of knowledge and books, the handwritten book (in the form of the Koran) seems to have been perceived to be holy but the printed book to be unholy by contemporary Muslims. In consequence Muslim beliefs, being influenced by the legitimacy of religious authorities, were possibly a fundamental driver of literacy and progress until the printing press when it reversed its stance on the dissemination of the word (in its printed form). The importance of the Muslim religious authorities for the generation of knowledge might have been similar to that of Christianity in the form of the Catholic Church. Whereas the Catholic Church was the most important defender of the literary tradition in Europe after the fall of the Roman Empire and a major supplier and demander of books through book production in monasteries, the political, economic and religious threats to its legitimacy caused by the printing press meant that it might have reversed its prior role as an overall promoter of knowledge. ${ }^{18}$

\section{Korea}

\subsection{The role of government policy and philosophical beliefs}

Finally let us turn to East Asia. East Asia was the most important economic and scientific hub for many centuries. Why was the printing press not invented in these advanced Asian societies? In fact it was invented earlier in East Asia than in Europe. However it did not have such a significant effect as in Europe. Some explanations for this paradox focus on the 'alphabet effect' [Logan 1986], i.e. that China and other countries did not have an alphabet but thousands of characters. The high number of characters considerably increased the costs of the production of movable types and of printed documents and gave disincentives to the use of movable type.

${ }^{18}$ However Logan believes that the role of the Catholic Church for scholarship was more limited, arguing that the Church "had a very narrow set of interests and [...] was not a very innovative institution. [...] Not many new scholarly works arose out of this milieu [...]. The one valuable service the Church provided to scholarship was preservation [...]. The efforts of the Church, together with the preservation of texts by the Islamic and Byzantine cultures, permitted the eventual transmission of Greek and Latin learning to Renaissance scholars" [Logan 1986: $171]$. 
In this context a fascinating case is Korea. Both movable metal type and a phonetic alphabet were invented in Korea before Gutenberg's printing press [Evon 2009]. ${ }^{19}$ Therefore the two most important fundamental technologies that were essential for Gutenberg's breakthrough existed in Korea. However a key difference to the European case is that in Korea the advantages of alphabetic print (i.e. the organisation of movable type focussing on individual letters) were not seen for many centuries and Korea has not adopted it until this day. The role of the government and philosophical beliefs are fundamental to understand the invention of the printing press and of the Korean alphabet. These elements further allow us to see the European case in the Asian mirror and to comprehend why the printing press had such a success and impact in Europe but not elsewhere.

First of all let us begin with the Korean language system. Literary Sinitic (i.e. Chinese characters) was used in Korea as a written language. Thus it was in some respects similar to the use of Latin in Europe. However, in contrast to Latin, Literary Sinitic was never used as an oral language. In fact Literacy Sinitic was basically a foreign language for Koreans. It was difficult to master, even for the Chinese. Given the particular respect for this writing system, this fact had the effect that the oral language and vernacular writing were devalued in the eyes of the Korean elites [Evon 2009].

This lack of appreciation of the vernacular language was further increased by the significance of Neo-Confucianism over many centuries, in particular during the Choson dynasty. This dynasty ruled Korea for many centuries from 1392 to 1910. Neo-Confucianism in the Korean orthodox interpretation was inherently intertwined with the predominant use of Literary Sinitic which some see as somewhat paradoxical and antagonistic to Confucian theory. ${ }^{20}$ To defend this orthodox interpretation of Confucian teachings the government had to control the use of Literary Sinitic and anything that was read. Hence Literary Sinitic had an important socio-political use [Evon 2009].

In addition this Neo-Confucian approach put emphasis on the moral aspects of knowledge and not its economic effects. As Sohn writes, "[s]ince a society oriented towards Confucianism did not favour the commercialization of book printing, the selling of books was disapproved" [Sohn 1959: 101]. Finally the mastering of Literary Sinitic necessitated high auditory and visual mnemonic skills and memory. This feature once again reinforced the neces-

${ }^{19}$ We are aware of the fact that there were periods in Korean history when it was divided amongst different rulers. To simplify matters we only refer to Korea as one country.

${ }^{20}$ For example, Evon points out that "Korean's overwhelming use of Literary Sinitic for verse was paradoxical due to the Confucian theory of poetry's socio-political function. In this conception, the oral/aural foundations of poetry were emphasised. Yet education in Literary Sinitic ran counter to this theory. Not only did it represent a radical disjunction between speech and writing, but moreover, it put the students' own vernacular in service of an unsayable language" [Evon 2009: 4-5]. 
sity of a stable knowledge base which was founded on the written word. In more general terms knowledge was seen to be permanent and not evolving. Thus the written word was the representation of this permanent knowledge and the means of expressing and communicating it. Therefore innovations in knowledge production could harm the knowledge base upon which society was built. In consequence they could menace the stability of the socio-political system [Evon 2009].

\subsection{Education and the beginnings of printing in Korea}

In correspondence to the high importance of Neo-Confucianism elite education was not aiming at particular commercial skills in Korea. Instead elite education focussed on mastering Literary Sinitic. ${ }^{21}$ Interestingly, "[w]ithout this, no other recognisable intellectual accomplishments were possible" [Evon 2009: $3]$. Therefore the oral language was not deemed to be important for the Korean elites, not even oral vernacular Chinese, nor written vernaculars. ${ }^{22}$

It is helpful to have a short glimpse at the educational history of Korea to better comprehend the centrality of Chinese characters and Confucianism. In fact the Korean education system was modelled on the Chinese system. This system was first brought to Korea in the $4^{\text {th }}$ century. Given the important influence of China, the demand for Chinese writings and especially Confucian teachings, increased over time. Furthermore the Chinese system of civil service examinations was adopted and used in Korea from the $10^{\text {th }}$ century. Thus the interest in Confucianism gained further ground. Another consequence of the examination system was the creation of new educational facilities, in particular the National Institutes of Higher Education and many new private schools. Clearly the creation of these different types of educational facilities, their relevance for the civil service and their competition brought about an increasing demand for books. This increased demand, in turn, made it necessary to print books. In consequence the government began to print books with woodblocks. Furthermore the rise of Buddhism in the region was another reason which led to increased printing activity. Accordingly the government printed a range of Buddhist works. Therefore demand grew in Korea for both Buddhist and Confucian materials [Sohn 1959].

${ }^{21}$ This ideology of elite education somewhat corresponds to the importance attributed to literacy skills in elite education in Europe, where numeracy skills and other practical skills were largely neglected for a many centuries [Hippe 2012a; see also Hippe 2012b; Hippe and Baten 2012]. However these literacy skills could often be used for oral communication in Europe which was not possible in Asia.

${ }^{22}$ In contrast Latin was challenged in Europe as a literature language by an ever increasing vernacular movement in literature. This movement originated in Italy around 1300 with Dantes works. Subsequently it spread to other countries such as England, France and Germany [Logan 1986]. 
In consequence domestic production became insufficient to satisfy this demand. Thus the government was eager to obtain books from abroad. An large number of books was imported from China. However there were voices in China against the export of books. In fact it was pointed out that China might lose competitiveness to Korea. Books may have been seen as a means of power. In addition a more powerful Korea might endanger Chinese security. However it was not until 1127 that Chinese book supplies to Korea were severely limited and this only because the Chinese (Sung) government had to flee to Southern China. In the same year the Korean royal palaces and libraries were destroyed in a royal power struggle, destroying a part of the royal book collection. Therefore a new situation arose in which domestic demand for books was very high but foreign supplies from China were (almost) unavailable and the domestic stock of books had been partly destroyed [Sohn 1959, 1993].

For these reasons supply-demand pressures may have incentivised the development of woodblock printing in Korea. However woodblock printing was not the ideal printing technology in Korea. Woodblock printing was a Chinese invention. Yet the type of wood normally used for woodblock printing in China was scarce in Korea limiting the further improvement of woodblock printing at a higher level. This lack of a crucial natural resource may have stimulated the use of other materials. Indeed Korea was very rich in metals and specialised in metallurgy. Therefore metal type casting was invented. In sum, "it is most probable that the invention of metal type casting was a result of the urgent need for book printing after 1127 [...], certainly before the Mongol invasion" [Sohn 1959: 98]. ${ }^{23}$ Sohn [1959] suggests that metal type casting was probably invented in either a religious or a military context. On the one hand the technical use of metals was particularly promoted by the army. The army used metals to manufacture arms and coins. ${ }^{24}$ On the other hand metals played an important role for Buddhists as they employed them for creating statues and other decorations. The Korean (i.e. Koryo) government at that time also actively promoted Buddhism by publishing Buddhist works. This connection was reversed by the Choson Dynasty (1392-1910) which favoured Neo-Confucianism.

In addition a printing press was a perfect means to facilitate the study of Chinese culture. Therefore new Chinese type casting methods were introduced in Korea in the $14^{\text {th }}$ century and these were merged with local knowhow in the use of metals to create a printing press using metal type casting [Sohn 1959].

${ }^{23}$ The Mongol invasions of Korea began in 1231.

${ }^{24}$ Similarly warfare was also a major driver of metallurgy in Medieval Europe. Logan points out that "the motivation for improvements in metal-working likely grew out of the increased violence of warfare made possibly by [...] the stirrup" [Logan 1986: 168]. 


\subsection{The Korean alphabet and the printing press}

Despite the central importance of Sinitic characters in Korea the Korean alphabet was invented in 1443 [Sohn 1993]. Buddhism appears to have had an impact on the proliferation of Korean alphabetic texts. In fact a range of Buddhist texts were written in the new alphabet in the bureau. Although the Korean King Sejong (reigning from 1418 to 1450) initially rejected Buddhism and enforced corresponding actions he might have been somewhat sympathetic to the religion. His deceased wife was a Buddhist. Still Buddhism was not a state religion in Korea anymore. Thus it had lost its economic foundations. This situation made it important for Buddhists to have an efficient writing system to diffuse their teachings. In consequence the alphabet was welcomed and extensively used by Buddhists [Evon 2009]. ${ }^{25}$

In contrast to what one might expect the new alphabet was never supposed to replace Literary Sinitic. The arguments for and against the creation of the script by King Sejong illustrate this. The loss of social control was one important argument raised by the elites against the introduction of the alphabet. More widespread reading in the population and higher literacy skills could lead to comments embarrassing the government, such as maladministration. In addition literacy should serve the study of Neo-Confucianism and Confucian moral values and this link could be endangered by the new alphabet. Similarly "if one could learn to read and write with ease, there would be no need for the labourintensive, time-consuming study required to master the classics upon which the business of government was based" [Evon 2009: 12; Lee 1993]. Therefore the legitimacy of the government would be in question. ${ }^{26}$

In light of these dangers why did King Sejong favour the construction of an alphabet? According to Lee [1993] he explicitly aimed at facilitating the communication amongst his (common) people because he sought to live up to Confucian values. In other words one could say that the constructed legitimacy, derived from Confucian philosophy, was very important for the king. Amongst others this meant that he strove to provide fairer legal proceedings because Literary Sinitic was not understood by the uneducated lower classes. The new alphabet, in contrast, could be learned rather quickly. But also in other respects the new alphabet was important for the king. First, the alphabet allowed the transcription of Chinese characters that did not have any equivalent in the Korean language.

${ }^{25}$ In some sense this fact parallels the use of the printing press for Protestant purposes in Europe. However in contrast to Buddhism, Protestantism had not previously been a state religion because it had not existed before. Still both Buddhism and Protestantism used the alphabetic script and the printing press, respectively, to facilitate the spread of their ideas, being confronted by a state religion.

${ }^{26}$ In addition the mastering of Literary Sinitic appears to have provided the social elites with an educational monopoly similar to the predominance of Latin in Europe. This monopoly would be potentially lost with the introduction of a new alphabet. 
Second, it was possible to translate portions into the vernacular language that did not have ambiguous equivalents in Korean. In sum, the new alphabet allowed an easier study of Literary Sinitic texts. Third, another important feature of the Korean alphabet was that it represented sounds much better. Therefore it could be used to write the vernacular Korean language [Evon 2009]. Finally, he was aware that not only the use of written Literary Sinitic was relevant for the government. Oral Chinese as practised at the Chinese court was also crucial. On the one hand he needed skilled translator-interpreters who were able to accurately transcribe the oral Chinese sounds. However just this was not possible with Literary Sinitic. On the other hand King Sejong was concerned with the training of his local elites. In fact there was no unique, accepted way of correctly pronouncing Chinese characters in Korea. For this reason there was a chaos of different pronunciations in the country. Therefore King Sejong needed the phonetic script of the alphabet to solve this problem which would facilitate governance in the future [Evon 2009].

However Chinese characters were still central in printing activities in Korea. In addition the king believed in Neo-Confucian traditional values which stated that the most important use of literature was for moral and ethical purposes. Commercial uses were not so important. The successive Korean governments had the exclusive and monopolistic control of the printing press technology which was developing mostly within the foundry of the royal dynasty. Therefore the dynasty's opposition to any commercialisation of printing activities significantly limited its use and dissemination. Only official printing activities were allowed and any other activities were suppressed. The wider circulation of new information and knowledge was seen by the elites as generating potential disorder and, hence, was deemed to be dangerous. ${ }^{27}$ In consequence the printing press was only helpful for the elites but not the wider society [Sohn 1959]. Thus the "protection of Choson's Neo-Confucian orthodoxy [...] entailed control over Literary Sinitic and this, in turn, required control over what was read" [Evon 2009: 16].

In economic terms one has to be aware that the Korean alphabet works in a different way than the Roman one. The Korean alphabet is organised around syllabic blocks and not individual letters as the Roman alphabet. This crucial difference has the effect that in the former case a Korean printer needs potentially 2350 individual syllables whereas in the latter he only needs the 24 letters

${ }^{27}$ Looking at the consequences of Gutenberg's invention the Korean elites might have been quite right in their interpretation because the European socio-political structure was rapidly shaken by the printing press. Indeed the use of the Korean alphabet was temporarily banned in Korea after a document (written with this alphabet) criticised the contemporaneous King Yeonsangun. In addition the king ordered that books in the Korean script were to be burned. Only years later, after his tyrannical reign was terminated by a coup, was the script revived [National Institute 2008]. 
of the alphabet [Evon 2009]. ${ }^{28}$ Therefore although this system has reduced the number of characters with regard to Sinitic characters it is still far more complex than the Roman system. ${ }^{29}$ Thus it is easy to see the economies that are possible with the use of alphabetic print. Therefore Gutenberg's success is in part directly derived from the underlying alphabet and its organisation around individual letters. Still the Korean alphabet might have had a much more significant impact if it had been used more widely. For example Sohn claims that "[i] $\mathrm{f}$ this excellent alphabet had been used, typography would have made a great impact on the Korean people just as it did in the West" [Sohn 1959: 101]. The lack of the new alphabet's use and the government's monopoly of the printing press meant that they did not cause increased entrepreneurship and wider reading activities which were fundamental for scientific and technological progress in Europe.

\section{The European, Ottoman and Korean experiences in perspective}

We have seen that the power struggle between the Church and the multitude of kings in Europe meant that power was shared between these institutions. Therefore the overall power was not as concentrated as in Korea or the Ottoman Empire. European countries were also actively competing against each other. For this reason it was not possible to effectively control the printing press and decree its non-utilisation in the European countries. However an outright ban of the printing press was not considered by the Church either. The control of the printing press opened many more possibilities. Although government and Church attempts to control the medium were important in Europe they were less successful than in the Ottoman Empire or Korea. Ottoman authorities could also learn from the European experiences and better understood the challenges the printing press posed to their authority [Pedersen 1984; Huff 1993; Cosgel, Miceli, and Rubin 2012]. Their religious convictions and their dependence on religious legitimacy further deteriorated their vision of the printing press so that they outlawed its use (in the Arabic script). In contrast Martin Luther saw printing as "God's highest and most extreme gift by which the business of the Gospel is driven forward" [Childress 2008: 122]. The contrast is quite striking. In Korea Buddhists also used the new alphabet to diffuse their teachings whereas (state-supported) Neo-Confucianism rejected it. 'Subversive' move-

\footnotetext{
${ }^{28}$ In fact theoretically there are many more combinations possible. More specifically there are 11,172 possible combinations but only the reduced number mentioned actually exists in the Korean language [Evon 2009].

${ }^{29}$ The Roman alphabet is based on the Phoenician alphabet.
} 
ments, such as Protestantism in Europe and Buddhism in Korea, clearly understood the benefits of the new ICT and used them correspondingly.

Thus the duality of European power structures and religious perceptions might have been a factor that involuntarily favoured the (more or less) efficient use of market forces that ultimately unleashed European economic success. The religious legitimacy conferred by the Church to secular rulers may have already been insufficient to enforce effective control according to its own imperatives. In contrast the philosophical legitimacy of Neo-Confucianism may have been the underlying power basis of the Korean rulers (during the Choson dynasty). Thus the government monopoly of the printing press in Korea meant that it could not unleash its effects as in Europe where it was in the hands of businessmen. Similarly to Korea the power of the central authorities in the Ottoman Empire combined with particular spiritual beliefs and legitimacies (in Korea the centrality or in some distant sense the 'holiness' of Literary Sinitic; in the Ottoman Empire, the holiness of the Arabic script) appear to have been major impediments to the commercial use of the printing press and thus the spread of ideas and knowledge which may have been crucial for Europe's future economic and socio-political development.

In addition, Guellec [2004] argues that the Chinese might not have moved to metal movable type printing because they had invented wood printing many centuries before Koreans invented the use of metals for the same purpose. For this reason the author suggests that the switching of costs from moving from one technology (woodblock printing) to another (metal movable type printing) might have been very high. Path dependency might, thus, be an important issue in this context of technology adoption. These switching costs were much lower in Europe because Europe was a late-comer that could directly use the new technology without incurring significant sunk costs. Korea might have also had higher sunk costs in the older technologies. In this sense we may suggest that Europe was perhaps leap-frogging at that time. ${ }^{30}$

Furthermore, in both Korea and Germany, the invention of the printing press with metal movable type was the result of a conscious perfectionist reassembling already existing technologies in areas which were specialised in the use of metals. Korea had already acquired sophisticated knowledge in metallurgy by the time of its invention of the printing press. The lack of a particular natural resource (i.e. a specific type of wood used for wood printing) meant that it may have concentrated its efforts in an area in which it was particularly good. In Germany Gutenberg's printing press was invented in Mainz, a city which was part of the Rhine valley. This valley was an important 'industrialised' re-

\footnotetext{
${ }^{30}$ Still woodblock printing was also used for smaller scale printing activities in Europe. In Korea woodblock printing was not replaced by metal movable type printing either. Instead both forms co-existed for different purposes.
} 
gion particularly specialised in metallurgy. Thus it could be seen as a 'Silicon Valley of metallurgy' of the $15^{\text {th }}$ century [Guellec 2004].

Accordingly the printing press was directly invented in a business context in Europe. Gutenberg's incentive was to have commercial success with his invention seeing that there was a high demand for such an invention [Guellec 2004]. In fact manuscript production had been increasing for almost a century in Germany [Neddermeyer 1996]. This evolution generated a demand pull for a new technology. The actions of Gutenberg could thus be seen as a consequence and culmination of a larger trend, and not the arbitrary inventiveness of one single person. ${ }^{31}$ Interestingly the case of Korea offers a similar story. Korean metal movable type printing was probably also invented as a response to a significant demand pull - although apparently neither for commercial incentive nor was it invented by a commercial entrepreneur. Instead it was probably invented in a religious or military setting [Sohn 1959].

Given Gutenberg's entrepreneurial spirit and the commercial context of its invention the diffusion of the printing press in the economy was possibly much easier attained in Europe than in Korea where it might have been invented in an environment more directly related to the government. In such a context the technology could be kept away more easily from the markets. The question that remains is why no individual in contact with the technology at the royal court in Korea attempted to use the printing press for his own commercial interests.

One could speculate that the loyalty to the king was an important factor. In addition the power of the king meant that such an individual would have to emigrate to another country in order to effectively use the technology and be safe from the punishment of the king. Finally the economic potential might not have been clearly seen given the predominance of Literary Sinitic and its associated high cost in printing thousands of characters. Comparing Europe with China Logan emphasises this point by stating that the European alphabet "permitted the mechanical production of large numbers of the same type fonts at relatively low cost, encouraging mass production. Relatively small-scale entrepreneurs were able to set up printing shops in every major urban centre in Europe. In China, however, it was only in government-sponsored enterprises that printing could be managed" [Logan 1986: 178, referring to Innis 1971].

${ }^{31}$ One fundamental prerequisite of the invention of the printing press was the availability of paper. The importance of paper can be highlighted that, still at the end of the $15^{\text {th }}$ century, the cost of paper represented about $50 \%$ of the production costs of a book [Febvre and Martin 1976; Guellec 2004]. Previously the cost of paper had already fundamentally decreased throughout the first half of the $15^{\text {th }}$ century. Note that paper first arrived in Germany in 1228 and its manufacturing only began in 1391, around 60 years before Gutenberg's invention [Gunaratne 2001]. After 1430 different techniques were invented by a number of individuals to produce more written materials with lower costs. These were also the years when Gutenberg began his investigations to create a printing press which took him about 15 years. However Gutenberg's invention eventually proved to be the best solution for book production [Guellec 2004]. 
In contrast the Korean alphabet consists of 24 letters. However remember that these are used in syllabic blocks and not as individual letters as in Europe. In consequence more than 2000 combinations would potentially be needed, increasing significantly the financial costs in any entrepreneurial undertaking and lowering any commercial incentives. The financial hurdle may have been simply too heavy. This fact may have also been central in limiting printing activities. ${ }^{32}$

Finally the market size of Korea might have also been much smaller than the potential market in Europe. In an historical perspective the existence of large consumers is often crucial for the initial success of new technologies [Guellec 2004]. The government was the most important potential client but the government had a monopoly on the technology. This contrasts sharply with Europe where the Catholic Church actively demanded printed books from private printers once the printing press was invented. Thus it represented a large and potentially reliable customer to businessmen. ${ }^{33}$

The same case could possibly be made for the Ottoman Empire. In addition religious beliefs, the importance of religious legitimacy combined with the political power of the Ottoman rulers might have been a major factor that the printing press was not introduced to the Ottoman Empire for centuries. The fact that religious beliefs were opposed to the use of the printing press may have both significantly discouraged the entrepreneurial spirit of individuals and decreased the potential demand for printed books. The power of the central authorities and their proscription of the printing press increased the financial and physical risk of any such enterprise.

These different reasons might have led to the fact that a potential groundbreaking innovation was not employed to the extent that it could have been used in Korea or the Ottoman Empire. In contrast Europe might have benefitted enormously from the printing press which lifted it into a new stage of knowledge production and a new era of sustained economic growth.

${ }^{32}$ Still one may wonder whether a more active policy for the diffusion of the Korean alphabet would have led to further innovations. In other words if the government had focused on reducing the printing costs and increasing the printing output, a demand pull could have motivated a change to a more Roman-style letter system. After all the invention of the Korean alphabet appears much more radical and innovative than a subsequent re-ordering of the existing alphabet. But, for sure, it would have needed a king like King Sejong or possibly an ingenious entrepreneur like Gutenberg.

${ }^{33}$ In addition clients normally ordered manuscripts ex-ante in Europe. This was dramatically changed by the printing press when individual clients were needed to be found ex-post in many cases [Guellec 2004]. This European way of manuscript production finds its counterpart in Korea and China where the government ordered manuscripts or printed documents. Therefore there might possibly not have been an entrepreneurial spirit of creating demand for a product (with its often high associated risks, but production was often only considered once it was explicitly ordered. Such a commercial perception would clearly also limit entrepreneurial activities in this area. 


\section{Conclusions}

This paper has analysed the role of governments in the knowledge transition. The knowledge transition describes the long-run transition from societies characterised by overall low levels of knowledge to the current explosion of knowledge. The printing press may have played a crucial role in this transition. In this paper the focus has been on the government's impact on the invention, adoption and dissemination of the printing press in the case of Europe, Korea and the Ottoman Empire.

The printing press using metal movable types was first invented in Korea but only Gutenberg's European invention led to a breakthrough in the production of knowledge. This is even more surprising as Korea was a country that possessed both the metal movable typing technology and later on an alphabet (in contrast to China which still uses Literary Sinitic). Nevertheless the printing press did not cause a major social, economic and political shift in this country, a major difference to Europe. In addition the Ottoman Empire, although an important economic, military and scientific power, did not adopt the printing press for printing the Arabic script for several centuries. Thus this paper emphasises the role of the governments which may have led to the different impact of the printing press in these three cases. Every case had its own sociopolitical structure based on specific legitimacies and its particular religious or philosophical beliefs (Christianity in Western Europe, Islam in the Ottoman Empire, Neo-Confucianism and Buddhism in Korea).

In particular religious authorities may have had a positive influence on the invention of the printing press in Germany and Korea. Gutenberg's endeavours to invent the printing press were driven by commercial interests. The Catholic Church had been producing manuscripts for centuries and its representatives were potentially interested in such an innovation. Overall demand for manuscripts had also been rising for almost a century. Therefore the Church as a potential large and reliable customer may have given him an important indirect incentive to continue working on a machine for many years. Moreover the European market was potentially huge. In contrast the Korean printing press may have been invented in a military unit or religious environment after a significant demand pull for printed materials. ${ }^{34}$ Whilst quickly rising demand played a crucial role in both cases the motivations may have been quite different - in Europe they were clearly commercial, in Korea they were possibly not. In a more general perspective future transformative innovations may possibly occur when there is a significant demand pull for them, coming from commerce, religion, the military or other areas. For example the threats of climate change may potentially generate a demand pull for cleaner technologies in the future.

\footnotetext{
${ }^{34}$ Note that also the next transformative ICT, the internet, was invented in a military context. That is, it was invented by the US military.
} 
Furthermore once the printing press was invented authorities may have feared the loss of important parts of their legitimacy which could have led to a loss of their power and rents. In Europe the Catholic Church saw the printing press at first as a tool to promote its faith and only too late understood the transformative (and for its organisation, subversive) character of the invention. Even if the Church had reacted earlier and would have wanted to suppress the printing press it would not have had sufficient power (see also Cosgel, Miceli, and Rubin 2012). Seeing its legitimacy and powerbase declining it reacted through censorship and control. However the plurality of European power relations and the self-interests of secular governments did not allow strict enforcement. Indeed European governments saw the potential to increase their own economic rents and were already sufficiently independent of the Church as a source of legitimacy. They attempted to control the printing business themselves but only with often temporary and incomplete success due to international competition and piracy.

In contrast Ottoman rulers were aware of the political consequences of this invention in Europe and feared the loss of their power and legitimacy (similar to the one of the Church) [Pedersen 1984; Huff 1993; Cosgel, Miceli, and Rubin 2012]. Religious authorities still conferred an important degree of the overall legitimacy to the rulers. Religious beliefs, in particular the sacredness of the Arabic script, may have been another factor in outlawing the printing of Arabic letters in their empire.

Similarly, although the Korean government was probably a major promoter of the invention of the printing press, it did not allow its commercial use given its Neo-Confucian values. The potential loss of philosophical legitimacy could also have played an important role in this case. Thus the government had a monopoly of this technology and controlled and limited printing. Whilst the Korean king invented the Korean alphabet in the $15^{\text {th }}$ century it was not supposed to replace the prevalent Sinitic characters. Sinitic characters were still predominantly used for more than the next 400 years. To some extent (although not comparable to Islamic traditions), Sinitic characters were also viewed as sacred in the Neo-Confucian tradition and the introduction of the new alphabet was opposed by the elites, having important vested interests in the status quo. In contrast Buddhism as a non state-sponsored religion used the advantages of the technology for its own purposes (similar to Protestantism in Europe). The specific characteristics of the alphabet (i.e. organisation of words around syllabic blocks) did not facilitate printing to the same extent as the Roman alphabet either. For these reasons the Korean printing press could not unfold its potential social, economic and political effects as in Europe where its commercial use and the competition amongst printers and nations were probably key elements of its success. In consequence, the printing press was an important factor leading to the transformation of power relations within society. 


\section{References}

Baten, J., van Zanden, J.L., 2008, Book Production and the Onset of Modern Economic Growth, Journal of Economic Growth, vol. 13: 217-235.

Brandt, L., Ma, D., Rawski, T.G., 2014, From Divergence to Convergence: Reevaluating the History Behind China's Economic Boom, Journal of Economic Perspectives, vol. 52, no. 1: 45-123.

Broadberry, S.N., 2013, Accounting for the Great Divergence, LSE Economic History Working Papers, no. 184, November 2013.

Buringh, E., van Zanden, J.L., 2009, Charting the "Rise of the West": Manuscripts and Printed Books in Europe, a Long-term Perspective from the Sixth through Eighteenth Centuries, Journal of Economic History, vol. 69, no. 2: 409-445.

Childress, D., 2008, Johannes Gutenberg and the Printing Press, Twenty-First Century Books, Minneapolis.

Cosgel, M.M., Miceli, T.J., Rubin, J., 2012, The Political Economy of Mass Printing: Legitimacy and Technological Change in the Ottoman Empire, Journal of Comparative Economics, vol. 40: 357-371.

Demeulemeester, J.L., Diebolt, C., 2011, Education and Growth: What Links for Which Policy?, Historical Social Research, vol. 36, no. 4: 323-346.

Dittmar, J.E., 2011, Information Technology and Economic Change: The Impact of the Printing Press, Quarterly Journal of Economics, vol. 126, no. 3: 1133-1172.

Eisenstein, E.L., 1979, The Printing Press as an Agent of Change, Cambridge University Press, New York.

Eisenstein, E.L., 2002, An Unacknowledged Revolution Revisited, American Historical Review, vol. 107, no. 1: 87-105.

Evon, G.N., 2009, The Conservation of Knowledge and Technology of the Word in Korea, Asian Studies Review, vol. 33: 1-19.

Febvre, L., Martin, H.-J., 1976, The Coming of the Book: The Impact of Printing, 1450-1800, New Left Books, London.

Feldman, S.M., 1997, Please Don't Wish Me a Merry Christmas: A Critical History of the Separation of Church and State, New York University Press, New York.

Finer, S., 1997, The History of Government from the Earliest Times, 3 volumes, Oxford University Press, Oxford.

Gibb, H., 1963, Arabic Literature, Oxford University Press, Oxford.

Guellec, D., 2004, Gutenberg revisité. Une analyse économique de l'invention de l'imprimerie, Revue d'économie politique, vol. 114, no. 2: 169-199.

Gunaratne, S.A., 2001, Paper, Printing and the Printing Press, Gazette, vol. 63, no. 6: 459-479.

Hesse, C., 2002, The Rise of Intellectual Property, 700 B.C.-A.D. 2000: An Idea in the Balance, Daedalus, vol. 131, no. 2: 26-45.

Hippe, R., 2012a, How to Measure Human Capital? The Relationship between Numeracy and Literacy, Economies et Sociétés, vol. 45, no. 8: 1527-1554.

Hippe, R., 2012b, Spatial Clustering of Human Capital in the European Regions, Economies et sociétés, vol. 46, no. 7: 1077-1104.

Hippe, R., Baten, J., 2012, Regional Inequality in Human Capital Formation in Europe, 1790-1880, Scandinavian Economic History Review, vol. 60, no. 3: 254-289. 
Hitti, P.K., 1964, The Arabs, University of Chicago Press, Chicago.

Houston, R.A., 1988, Literacy in Early Modern Europe: Culture and Education, 1500-1800, Longman, London.

Huff, T.E., 1993, The Rise of Early Modern Science, Cambridge University Press, Cambridge.

Innis, H., 1971, Empire and Communication, Toronto.

Johns, A., 1998, The Nature of the Book: Print and Knowledge in the Making, University of Chicago Press, Chicago.

Kertcher, Z., Margalit, A.N., 2005, Challenges to Authority, Burdens of Legitimization: The Printing Press and the Internet, Yale Journal of Law \& Technology, vol. 8: 1-31.

Kreiser, K., 2001, The Beginnings of Printing in the Near and Middle East: Jews, Christians and Muslims, Harrassowitz Verlag, Wiesbaden.

Landes, D.S., 2006, Why Europe and the West? Why Not China?, Journal of Economic Perspectives, vol. 20, no. 2: 3-22.

Lee, P.H. (ed.)., 1993, Sourcebook of Korean Civilization, vol. I: From Early Times to the Sixteenth Century, Columbia University Press, New York.

Logan, R.K., 1986, The Alphabet Effect. The Impact of the Phonetic Alphabet on the Development of Western Civilization, St. Martin's Press, New York.

Macioti, M., 1989, Innovation and Diffusion of Technology: an Example of the Printing Press, Impact of Science on Society, vol. 39, no. 2: 143-50.

Martin, H.J., 1988, Histoire et pouvoirs de l'écrit, Albin Michel, Paris.

Mokyr, J., 2005, Long-Term Economic Growth and the History of Technology, in: Aghion, P., Durlauf, S.N. (eds.), The Handbook of Economic Growth, vol. 1B, Elsevier, Amsterdam.

Mokyr, J., 2011, The Enlightened Economy: Britain and the Industrial Revolution, 1700-1850, Penguin Books, London.

National Institute of the Korean Language, 2008, Chronology of Hangeul, online, http:// www.korean.go.kr/eng_hangeul/supply/pop04.html [access: 20.06.2014].

Neddermeyer, U., 1996, Möglichkeiten und Grenzen einer quantitativen Bestimmung der Buchproduktion im späten Mittelalter, Gazette du livre médiéval, vol. 28: 23-32.

Pedersen, J., 1984, The Arabic Book, Princeton University Press, Princeton.

Pomeranz, K., 2000, The Great Divergence: China, Europe, and the Making of the Modern World Economy, Princeton University Press, Princeton.

Putnam, G.H., 1906, The Censorship of the Church of Rome and Its Influence upon the Production and Distribution of Literature, Putnam, New York and London.

Roper, G., 2007, The Printing Press and Change in the Arab World, in: Baron, S.A., Lindquist, E.N., Shevlin, E.F. (eds.), Agent of Change: Print Culture Studies after Elizabeth L. Eisenstein, University of Massachusetts Press.

Rubin, J., 2013, Printing and Protestants: An Empirical Test of the Role of Printing in the Reformation, Review of Economics and Statistics, doi:10.1162/REST_a_00368.

Shleifer, A., 1987, Mass Communication and the Technicalization of Muslim Societies, Muslim Education Quarterly, vol. 4, no. 3: 4-12.

Sohn, P.K., 1959, Early Korean Printing, Journal of the American Oriental Society, vol. 79, no. 2: 96-113.

Sohn, P.K., 1993, Printing since the 8th Century in Korea, Koreana: 5-9.

Steinberg, S.H., 1959, Five Hundred Years of Printing, British Library \& Oak Knoll Press, London. 
The New Encyclopaedia Britannica, 1998, Printing, Typography, and Photoengraving, Vol. 26, Encyclopaedia Britannica, Chicago: 71-111.

Tierney, Bz., 1988, The Crisis of Church and State 1050-1300, University of Toronto Press, Toronto.

Tilly, C., 1992, Coercion, Capital, and European States, AD 990-1992, Blackwell, Cambridge.

Voigtländer, N., Voth, H.J., 2012, The Three Horsemen of Riches: Plague, War, and Urbanization in Early Modern Europe, Review of Economic Studies, vol. 0: 1-38.

Walraven, B., 2007, Reader's Etiquette, and Other Aspects of Book Culture in Choson Korea, in: Idema, W.L. (ed.), Books in Numbers, The Chinese University Press, Hong Kong: 237-265.

White, L., 1962, Social Change and Medieval Technology, Claredon Press, Oxford. van Zanden, J.L., 2009, The Long Road to the Industrial Revolution: The European Economy in a Global Perspective, 1000-1800, Koninklijke Brill NV, Leiden. 